



\section{Estimating requirement values for apparent faecal digestible and standardised ileal digestible valine in broilers by a meta-analysis approach}

T. Veldkamp, J.W. van Riel, R.A. Dekker, S. Khalaji, V. Khaksar, H. Hashemipour, M.M. van Krimpen and M.C. Blok 
T. Veldkamp, J.W. van Riel, R.A. Dekker, S. Khalaji, H. Hashemipour, M.M. van Krimpen and M.C. Blok. Estimating requirement values for apparent faecal digestible and standardised ileal digestible valine in broilers by a meta-analysis approach; Wageningen UR (University \& Research centre) Livestock Research, Livestock Research Report 970.

(c) 2016 Wageningen UR Livestock Research, P.O. Box 338, 6700 AH Wageningen, The Netherlands, T +31 (0)317 4839 53, E info.livestockresearch@wur.nl, www.wageningenUR.nl/en/livestockresearch. Livestock Research is part of Wageningen UR (University \& Research centre).

All rights reserved. No part of this publication may be reproduced and/or made public, whether by print, photocopy, microfilm or any other means, without the prior permission of the publisher or author.

The ISO 9001 certification by DNV underscores our quality level. All our research commissions are in line with the Terms and Conditions of the Animal Sciences Group. These are filed with D四 the District Court of Zwolle.

Confidential Livestock Research Report 970 - http://dx.doi.org/10.18174/388751 


\section{Table of contents}

$\begin{array}{ll}\text { Foreword } & \mathbf{5}\end{array}$

$\begin{array}{ll}\text { Summary } & 7\end{array}$

$\begin{array}{lll}1 & \text { Introduction } & 9\end{array}$

2 Material and Methods $\quad 10$

$\begin{array}{llr}2.1 & \text { Database } & 10\end{array}$

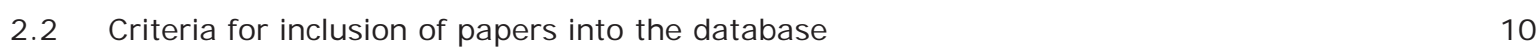

$\begin{array}{ll}2.3 & \text { Calculations } \\ 2.4 & 11\end{array}$

$\begin{array}{lll}2.4 & \text { Statistical analysis } & 11\end{array}$

2.4.1 Regression analysis per experiment 11

1.1.1 Overall regression (Regression analysis over experiments) 12

$\begin{array}{llr}3 & \text { Valine requirement values } & 14\end{array}$

$\begin{array}{llr}3.1 & \text { Valine background information on meta-analysis } & 14\end{array}$

$\begin{array}{lll}3.1 .1 & \text { Study details individual studies } & 14\end{array}$

3.1.2 Results of curve fitting and valine requirements for individual studies $\quad 14$

1.1.2 Results of overall curve fitting and valine requirements as a function of age $\quad 15$

$\begin{array}{ll}3.2 & \text { Valine requirement values } \\ \end{array}$

3.2.1 Requirement of AFD valine expressed on dietary content for body weight gain $\quad 15$

3.2.2 Requirement of AFD valine expressed on dietary content for feed conversion ratio 16

3.2.3 Requirement of SID valine expressed on dietary content for body weight gain 16

3.2.4 Requirement of SID valine expressed on dietary content for feed conversion ratio 17

3.3 Requirement values of valine on AFD and SID basis, expressed as content in the diet at $\begin{array}{ll}\text { different ages for BWG and FCR } & 17\end{array}$

$\begin{array}{ll}\text { Acknowledgement } & 19\end{array}$

$\begin{array}{ll}\text { Literature } & \mathbf{2 0}\end{array}$

$\begin{array}{ll}\text { Appendices } & \mathbf{2 1} \\ \end{array}$ 



\section{Foreword}

Diet composition, e.g. concentrations of energy, protein, vitamins and minerals, largely influence the zootechnical performance of poultry. Nowadays, protein requirements are more precisely described in terms of apparent faecal digestible amino acid (AFD) or standardised ileal digestible amino acid (SID) requirement values and amino acid profiles expressing the requirement of each amino acid relative to valine. Appropriate requirement values for amino acids (AA) in poultry diets are essential for optimizing poultry production and profit of the poultry chain.

CVB, formerly part of the Dutch Product Board Animal Feed (PDV) and now part of the Federatie Nederlandse Diervoedingsketen (FND; Federation Dutch Animal Feed Chain), is responsible for recommending the Dutch poultry chain on AA requirements for various poultry species. The latest public review of AA requirements in poultry in the Netherlands was presented two decades ago (Schutte et al., 1996). As a consequence of several recent developments such as change in genetic predisposition for growth, the increasing trend of formulating low-protein diets and the increasing availability of free AA for supplementation in broilers diets, it was recommended that requirement values for AA in broiler diets should be updated. The present study was subsidized by the (former) Product Board Animal Feed and the (former) Product Board Poultry and Eggs. 


\section{Summary}

Requirement values for apparent faecal digestible and standardised ileal digestible valine of broilers at different ages were estimated by a meta-analysis approach. This study was part of a project to estimate the apparent faecal (AFD) and standardized ileal digestible (SID) amino acid requirement values of the first limiting amino acids in both broilers and laying hens.

Peer reviewed papers were selected, describing experimental results of dose response studies in which the effect of graded levels of free amino acids supplemented to a basal diet on body weight gain and feed conversion ratio in broilers was studied. The papers searched for were published during the period 1994 - 2012. Subsequently, a stepwise process was applied for the selection of the research data to be used in the meta-analysis. In total 11 criteria were set. Two of these criteria are: at least three graded levels of supplementation of the amino acid of interest to the same basal diet; maximal supplementation of the amino acid of interest was at least $10 \%$ higher compared to the concentration of the amino acid of interest in the basal (non-supplemented) diet. Feed ingredient composition of the experimental diets should be present in each paper; this information was included in a separate database and nutrient composition of the experimental diets was recalculated by using data on the nutritional composition of the individual feed ingredients according to the CVB Feed Table (2007). When the determined level of the amino acid of interest (and - when presented - of other amino acids) on an AFD basis was published, this information was used. In case this information was not presented, the level of the amino acid of interest (and of other amino acids) was calculated by using either the total amino acid levels in the basal diets as analysed by the authors or as calculated by using the CVB Feed Table (2007) in combination with the digestibility on an AFD basis as published by CVB (CVB Table, 2007) In addition, the concentrations of standardized ileal digestible (SID) amino acids in the diets of each study were also calculated using the digestibility on an SID basis as tabulated by CVB (Dekker and Blok, 2015) and included in the database. These (calculated) dietary concentration of AFD and SID amino acids were used in the present study for the regression analyses to derive requirement values for AFD and SID amino acids in broilers.

The responses of body weight gain (BWG) and feed conversion ratio (FCR) to supplementation of the free amino acid of interest to a basal diet were analysed for each individual experiment included in the database by regression analysis. Mean data for BWG and FCR per experimental group as provided in the original paper were used as response parameters. Response of BWG and FCR to supplementation of the free amino acid of interest was determined by use of an exponential model. For each individual experiment the estimated requirement (Req) for the amino acid of interest was calculated as the amino acid concentration at which 95\% of the response (BWG and FCR) between intercept and asymptotic value was reached. Data of studies that could not be fitted with the exponential model were excluded from further evaluation. Also studies, where the estimated requirement value was over $110 \%$ of the maximum concentration of the amino acid of interest in the diet with the highest supplementation level, were excluded from further evaluation. Studies in which a non-test amino acid might have been co-limiting ( $<90 \%$ of CVB 1996) at higher supplementation levels of the amino acid of interest were also excluded from the dataset. After estimation and evaluation of the amino acid requirement values for the individual studies, an overall regression model was used to fit the requirement values of the amino acid of interest on an AFD and SID basis for BWG and FCR as a function of age of the broilers. For this purpose the mean age of broilers in each experiment was calculated as (age at start of the experimental period + age at the end of the experimental period)/2. In total, 12 studies each containing one or more experiments, were judged. In total, 4 experiments from 2 papers that met the criteria were included into the database. The relation between the valine requirement for BWG on AFD and SID basis and age was not significant. The relation between the valine requirement and age for FCR on AFD basis was significant $(P<0.001)$ and also the relation between the valine requirement and age for FCR on SID basis was significant $(P=0.005)$. Until 14 days of age the AFD and SID valine requirement values for FCR are slightly higher than the CVB (1996) recommendations for AFD valine requirement. From 17 days of age AFD and SID valine requirement values for FCR were lower than the CVB (1996) recommendations for AFD valine requirement. A summary is presented in the Table. 


\begin{tabular}{cccccc} 
Day & AFD valine (\% in diet) & AFD valine ( $\%$ in oliet) & \multicolumn{2}{c}{ SI D valine (\% in oliet) } \\
CVB (2007) & $\begin{array}{c}\text { Body weight } \\
\text { gain }\end{array}$ & $\begin{array}{c}\text { Feed } \\
\text { conversion } \\
\text { ratio }\end{array}$ & $\begin{array}{c}\text { Body weight } \\
\text { gain }\end{array}$ & $\begin{array}{c}\text { Feed } \\
\text { conversion } \\
\text { ratio }\end{array}$ \\
\hline 7 & 0.84 & - & 0.97 & - & 0.97 \\
\hline 14 & 0.82 & - & 0.84 & - & 0.85 \\
\hline 21 & 0.82 & - & 0.76 & - & 0.77 \\
\hline 28 & 0.79 & - & 0.70 & - & 0.72 \\
\hline 35 & 0.79 & - & 0.66 & - & 0.68 \\
\hline 42 & 0.79 & - & 0.63 & - & 0.65 \\
\hline
\end{tabular}




\section{Introduction}

Diet composition, e.g. concentrations of energy, protein, vitamins and minerals, largely influence the zootechnical performance of poultry. Nowadays, protein requirements are more precisely described in terms of digestible amino acid requirements and amino acid profiles expressing the requirement of each amino acid relative to lysine. Appropriate digestible amino acid requirements in poultry diets are essential for optimizing poultry production and profit of the poultry chain.

CVB, formerly part of the Dutch Product Board Animal Feed (PDV) and now part of the Federatie Nederlandse Diervoedingsketen (FND; Federation Dutch Animal Feed Chain), , is responsible for advising the Dutch feed industry on nutrient requirements for various poultry species. The latest public review of amino acid requirements in poultry in the Netherlands, however was conducted two decades ago (CVB, 1996). The requirement values of amino acids (CVB, 1996) were expressed on an apparent faecal digestible (AFD) basis. As a consequence of several recent developments, it was recommended that amino acid requirements should be updated:

- The genetic predisposition for growth of broilers has increased substantially during the last decades;

- $\quad$ The increasing trend of formulating low-protein diets;

- The increasing availability of free amino acids for diet supplementation;

- Different feeding strategies are developed to improve animal welfare and (intestinal) health.

Nutrient requirements have been determined in many experiments. A general method for integrating quantitative knowledge from multiple experiments has been proposed and is referred to as metaanalysis (St-Pierre, 2001). The technique is based on collecting data from multiple published studies, that fulfil a number of criteria and formulating a statistical model that best explains the observations (van Houwelingen et al., 2002). Moreover, the meta-analytical approach is highly suited for establishing requirements values because it focuses on estimating on a population level from multiple studies, while accounting for the heterogeneity between studies. The statistical model used in metaanalytical studies should be based on a hierarchical or a mixed model, which has at least two stages (van Houwelingen et al., 2002). The first-stage hierarchy models the within-study variability as a function of the primary covariate (e.g., Lys content). The second-stage hierarchy models the betweenstudy variability through individual random effects and study-related covariates (e.g. strain, gender, year of publication etc.), identifying systematic trends among studies.

Meta-analysis, which combines the results from various experiments at the same time, has more power to detect small differences. For estimating amino acid requirement values by use of a metaanalysis approach, formulating criteria for inclusion or exclusion of studies is very important. The main requirement for a proper meta-analysis is a well-executed systematic review. Therefore in the current work, key journals were hand searched and reference lists of papers were checked carefully.

The current requirement values for amino acids in broilers (CVB, 1996) are expressed on an apparent faecal digestible (AFD) basis. For the present study it was recommended by CVB to estimate requirement values for amino acids in broilers on a standardized ileal digestible basis. According to Lemme et al. (2004) and Adedokun et al. (2008) standardised ileal amino acid digestibility (SID) coefficients are corrected for the contribution of amino acids of basal endogenous origin to the total ileal digesta pool. Changing the system of expressing amino acid requirement values based on AFD into SID amino acid concentration of dietary ingredients affect the amino acid requirement values of broilers. It is important that amino acid requirement values and the dietary supply of amino acids are expressed identically.

The present study was part of a project conducted to estimate requirement values for the first limiting apparent faecal digestible (AFD) and standardized ileal digestible (SID) amino acids in broilers and laying hens at different ages using a meta-analysis approach. In this report the requirement values for valine are described. 


\section{$2 \quad$ Material and Methods}

\section{$2.1 \quad$ Database}

Peer reviewed papers were selected, describing experimental results of dose response studies in which the effect of graded levels of free amino acids of interest supplemented to a basal diet on body weight gain (BWG) and feed conversion ratio (FCR) in broilers was studied. The papers were searched by using the key words 'broiler' and 'name of relevant amino acid' in the electronic database 'Web of Science'. The papers searched for were published during the period 1994 - 2012. Search results in which the requirement of valine was studied were found in Animal Feed Science and Technology, British J ournal of Poultry Science, J ournal of Applied Poultry Research and Poultry Science. A stepwise process was applied for the selection of research data to be used.

\subsection{Criteria for inclusion of papers into the database}

The studies were reviewed according to the following inclusion criteria:

1. The experimental procedure should be adequately provided, meaning a clear description of the experimental units, the number of broilers per unit, the age of the broilers and the duration of the experiment;

2. Provision of information on the broilers used (strain, age);

3. Provision of information on the (metabolizable) energy content of the diets (for adult cockerels);

4. Provision of information on how amino acid levels in the basal diet(s) in the paper are expressed (total, faecal, ileal, on an apparent or standardized basis);

5. Only dose response studies were included in which besides a basal level of the amino acid of interest at least three graded levels of supplementation of the amino acid of interest to the same basal diet were tested;

6. Only dose response studies were included in which the maximal supplementation of the amino acid of interest was at least $10 \%$ higher compared to the concentration of the amino acid of interest in the basal (non-supplemented) diet;

7. With the exception of the concentration of the amino acid of interest (that should be - far below the CVB requirement), the concentration of the following amino acids in the basal diet should be at least $90 \%$ of the CVB (1996) requirement (on AFD basis) for lysine, methionine+cysteine, threonine and tryptophan. For isoleucine and arginine the concentration in the basal diet should be at least $85 \%$ of the CVB (1996) requirement (on AFD basis), because the requirements of these amino acids were documented less accurately.

8. Experimental diets should be adequately described in terms of ingredient composition and should contain analysed or calculated contents for at least crude protein and essential amino acids;

9. Feed intake levels of experimental groups (receiving the diets with supplemented free amino acid) within the same experiment should be less than $150 \%$ relative to the feed intake level of the group fed the basal (supplemented) diet;

10. Provision of data on feed intake, BWG and FCR in dose response studies with broilers in which the effects of increasing levels of the dietary amino acid of interest was evaluated by supplementing a basal diet with different levels of the free amino acid of interest;

11. Supplementation of the free amino acid of interest to the basal diet should have a statistical significant effect on BWG and/or FCR according to the original author.

Information of the papers that met these inclusion criteria was included in a database. Besides the information on the inclusion criteria as mentioned above, additional information from the study (if 
available) was added also to the database (e.g. strain, sex, etc.). Further the amino acid requirement value as derived by the original author(s) of the study was included in the database as well and also the statistical method they used to estimate the amino acid requirement under study was included. Studies not meeting the inclusion criteria as mentioned above, were excluded from the database and the reason for exclusion was recorded (See Appendix 1).

\subsection{Calculations}

Feed ingredients in the basal diet composition used in each experiment of studies that met the criteria in Paragraph 2.2 were included in a separate database. Subsequently nutrient composition of these experimental diets was recalculated by using data on the nutritional composition of the individual feed ingredients according to the CVB Feed Table (2007). Regarding the levels of digestible amino acids the following procedure was used:

a. When the paper presents the level of valine in the basal diets expressed on a (apparent faecal) digestible basis, it was decided to use this figure. As far as the levels of one or more other amino acids (see criterion 7 for the other amino acids that were considered to be relevant), were also expressed on this basis, this information was used in the further processing of the study. For those amino acids for which this information was lacking, the level of digestible amino acid was calculated according to option b. or c.;

b. When no information was presented in the paper on the level of (apparent) faecal digestible valine and/or other amino acids, the next option was to use the total level of valine and/or of the other amino acids as analysed in the basal diets. Using the faecal amino acid digestibility of the feed ingredients in the CVB Feed Table (2007), the faecal digestibility of the amino acids in the basal diet and, subsequently, the level of apparent faecal digestible amino acids was calculated;

c. When no information as described in the options a. and b. was available, the total levels of the amino acids needed were calculated using the ingredient composition of the experimental diets (see criterion 8) as presented in the paper. In these cases the starting point was the ingredient composition (Weende analysis, ME value and amino acid pattern) as published in the CVB Feed Table 2007. To reproduce satisfactory the level of crude protein and - when given - the metabolizable energy level as given in the paper, in a number of cases slight adjustment of the protein level and - as a consequence - the amino acid levels of - preferably - the protein rich ingredients was necessary. Subsequently the digestible amino acid levels on an AFD basis were calculated using the digestibility in the CVB Feed Table (2007).

In addition, the concentrations of standardized ileal digestible (SID) amino acids in the basal diets of each study were also calculated using option b. or c. and were included in the database. The standardized ileal amino acid digestibility coefficients of feed ingredients required for the calculation of SID amino acid contents were derived from Dekker and Blok (in press).

The supplemented free amino acids were considered to be $100 \%$ digestible, both on an AFD and SID basis.

The calculated dietary concentrations of AFD and of SID valine were used in the present study for the regression analyses to derive requirement values for valine on an AFD and SID basis for Body Weight Gain (BWG) and Feed Conversion Ratio (FCR) in broilers.

\section{$2.4 \quad$ Statistical analysis}

\subsubsection{Regression analysis per experiment}

The responses of BWG and FCR to supplementation of the free amino acid of interest to a basal diet were analysed by regression analysis. Mean data for BWG and FCR per experimental group as provided in the original paper were used as response parameters. The response of BWG and FCR to supplementation of free amino acid of interest was determined by use of an exponential model as is described by the following mathematical equation:

$\mathrm{Y}_{\mathrm{ij}}=\mathrm{a}_{i}+b_{i} *\left(1-\mathrm{e}^{(-\mathrm{Ci} * d x)}\right)+\underline{\varepsilon i j}$ (1) 
Where: $\mathrm{Y}_{\mathrm{ij}}=$ response value of BWG or FCR for experiment $\mathrm{i}$ and treatment $\mathrm{j}$;

$\mathrm{a}_{\mathrm{i}} \quad=$ estimated basal level (for $\mathrm{dx}=0$ ) of the amino acid of interest for experiment $\mathrm{i}$;

$b_{i} \quad=$ difference between basal level and estimated asymptotic level for body weight gain and feed conversion ratio response for experiment $i$;

$\mathrm{C}_{\mathrm{i}}=$ rate parameter (for speed of curving) for experiment $\mathrm{i}$;

$\mathrm{dx}=$ difference in amino acid concentration of interest (AFD or SID based) compared to basal (non-supplemented diet) in experiment i $\left(X_{i}-\operatorname{MIN}\left(X_{i}\right)\right) ; X_{i}=$ amino acid concentration of interest in experimental diets, $\mathrm{MIN}\left(\mathrm{X}_{\mathrm{i}}\right)=$ amino acid concentration of interest in basal (non-supplemented) diet;

$\varepsilon i j=$ error $\mathrm{ij}$.

For each individual experiment the estimated requirement (Req) for the amino acid of interest was calculated as the amino acid concentration where $95 \%$ of the response (BWG and FCR) between intercept and asymptotic value was reached. The estimated amino acid requirement was calculated by the following mathematical equation:

$\operatorname{Req}_{i}=\frac{\ln (0.05)}{-C i}+\mathrm{MIN}(\mathrm{Xi}) \quad(\mathbf{2})$

Where: Req $_{i}=$ Estimated amino acid requirement (\%) of the individual experiment $\mathrm{i}$;

$\operatorname{Ln}(0.05)={ }^{e} \log (0.05) ;$

$\mathrm{C}_{\mathrm{i}} \quad=$ rate parameter (for speed of curving) for experiment $\mathrm{i}$;

$\mathrm{MIN}\left(\mathrm{X}_{\mathrm{i}}\right)=$ amino acid $(\%)$ in basal (non-supplemented) diet.

\subsubsection{Overall regression (Regression analysis over experiments)}

After estimation of the amino acid requirement values for individual studies by using the exponential model according to equation 2, the amino acid requirement as a function of age was studied.

However, before doing this the results from the previous step were evaluated according to the following criteria:

- $\quad$ Mean age of the animals.

The mean age of broilers was determined in each experiment as (days of age at start of the experimental period + days of age at the end of the experimental period)/2. Experiments in which the mean age was $>42$ days were excluded from the database for the overall regression.

- $\quad$ Calculated requirement (as the AFD or SID amino acid level at which 95\% of the plateau level was reached) was compared to the highest dietary amino acid level in the experiment.

When the calculated requirement was $>110 \%$ of the amino acid level in the treatment with the highest supplemented amino acid level, the study was excluded from the database for the overall regression

- $\quad$ Lack of fit.

Studies in which no requirement could be estimated according to equation 2 were excluded from the database for the overall regression.

- Co-limitation of other amino acids

In the first review (see paragraph 2.2, criterion 7) only studies were included in the database when, besides the concentration of the amino acid of interest, the concentration of several other essential amino acids in the basal diet was at least $90 \%$ or $85 \%$ (depending on the amino acid) of the requirement (on AFD basis) according to CVB (1996). In this second review it was evaluated if the ratios of these amino acids relative to the amino acid of interest on an AFD basis were at least 0.90 of the ratio of the requirement of the same amino acids on an AFD basis according to CVB (1996). In formula:

(level non test amino acid $X$ basal diet in $\left.s t u d y_{i}\right) /\left(\right.$ calculated requirement test amino acid in study $y_{i}$ ) $\geq 0.90 *$ (requirement non test amino acid X, CVB 1996)/( requirement test amino acid, CVB 1996).

The regression model for the requirement of SID amino acid content and AFD amino acid content is described by the following mathematical equation:

$\operatorname{Req}_{i}=ß_{0}+ß_{1} * \ln \left(A_{g e}\right)+\underline{\varepsilon i}(3)$ 
Where: $\operatorname{Req}_{\mathrm{i}} \quad=$ amino acid requirement (content ( $\%$ in diet) $)$

$B_{0}=$ estimated amino acid requirement at hatch

$B_{1}=$ estimated linear effect of $\ln ($ Age $)$

$\ln \left(\right.$ Age $\left._{\mathrm{i}}\right)={ }^{\mathrm{e}} \log ($ Age $\mathrm{i})$

Age $\quad=$ average age of broilers in experiment $(\mathrm{d})$

Selection of candidate models with more factors included such as strain, gender, year, length of the experimental period, was not possible because of the restricted number of experiments that were accepted for overall regression analysis 


\section{Valine requirement values}

\subsection{Valine background information on meta-analysis}

\subsubsection{Study details individual studies}

In total, 12 studies each containing one or more experiments, were judged. Table 1 provides an overview of the 4 experiments from 2 papers that met the criteria for inclusion into the database. The procedure used to calculate the level of apparent faecal digestible valine (see Par. 2.3) is also mentioned. The number of valine supplementation levels per experiment was 6 . The data in the database covered various age periods of birds. In these 4 experiments males were used. Different strains were used in the experiments. In 3 experiments Ross 308 broilers were used and in 1 experiment ISA 220.

Papers that were not included in the database because studies did not meet the inclusion criteria are presented in Appendix 1

\section{Table 1}

List of List of references that met the inclusion criteria for further evaluation of the Valine requirement of broilers in the present study.

\begin{tabular}{|c|c|c|c|c|c|c|}
\hline $\begin{array}{l}\text { Experiment } \\
\text { number }\end{array}$ & Reference & $\begin{array}{l}\text { Nr. of } \\
\text { dose } \\
\text { levels }\end{array}$ & $\begin{array}{c}\text { Range of AFD } \\
\text { Val content } \\
(\mathrm{g} / \mathrm{kg})\end{array}$ & $\begin{array}{l}\text { Age of } \\
\text { broilers } \\
\text { (d) }\end{array}$ & Gender & Strain \\
\hline $41^{\mathrm{b})}$ & Corzo et al. 2008 & 6 & $0.64-1.04$ & $1-14$ & Male & Ross 308 \\
\hline $42^{b)}$ & Corzo et al. 2008 & 6 & $0.62-0.97$ & $14-28$ & Male & Ross 308 \\
\hline $43^{b)}$ & Corzo et al. 2008 & 6 & $0.54-0.89$ & $28-42$ & Male & Ross 308 \\
\hline $71^{\text {a) }}$ & Mack et al. 1999 & 6 & $0.56-0.83$ & $20-40$ & Male & ISA 220 \\
\hline
\end{tabular}

a): Digestible Val level (on AFD basis) in basal diet analysed by authors and used in present study.

b): Total Val level in basal diet analysed by authors and used in present study; calculation of digestible Lys level (on AFD basis) in basal diet was done by using these data in combination with the AFD coefficients in the CVB Feed Table (2007).

\subsubsection{Results of curve fitting and valine requirements for individual studies}

In general, the response of BWG and FCR to AFD and SID valine content in the experimental diet showed an exponential relationship, when using as input data the mean data for BWG and FCR per experimental group as provided in the original paper. The response of BWG and FCR to graded supplementation levels of dietary valine was determined for all individual experiments according to exponential model (1) described in paragraph 2.4.1.

The requirement for AFD and SID valine was determined for each study and defined as the dietary valine concentration at which $95 \%$ of the response (difference between performance at no additional valine supplementation and the performance at the asymptotic value) was met according to model (2) described in the paragraph 2.4.1.

The results of fitting the individual studies according to equation(2) in the paragraph 2.4.1, together with details of the study and estimated AFD valine requirement and SID valine requirement for BWG and FCR are presented in Appendix 2 and 3, respectively. In these Appendices only the results of studies are presented that also met the criteria for inclusion for the overall analysis in paragraph 2.4.2. 


\subsubsection{Results of overall curve fitting and valine requirements as a function of age}

For estimating the AFD and SID valine requirement as a function of age, an overall regression analysis was conducted on AFD and SID valine requirement values derived from the individual experiments and the mean age in these experiments according to the general model (3) described in paragraph 2.4.2. An overview of experiments that were included in the overall regression analysis of the experiments is presented in Appendix 4 and 5. Details of the individual experiments and estimated AFD valine requirement and SID valine requirement for BWG and FCR are presented in these appendixes as well. Some studies had to be excluded from the overall fitting for both BWG and FCR because of colimitation of other amino acids or lack of fit (see Appendix 6 and 7).

The results of the overall fitting are presented in Paragraph 3.2 (figures 1-4) and in Paragraph 3.3 (Table 2).

\subsection{Valine requirement values}

In paragraph 3.2.1 up to paragraph 3.2.4 the results of the overall regression analyses on requirement values derived from individual experiments are presented in graphs. Valine requirement values in these paragraphs are expressed on AFD or SID content in the diet and are expressed for BWG as well as FCR.

3.2.1 Requirement of AFD valine expressed on dietary content for body weight gain

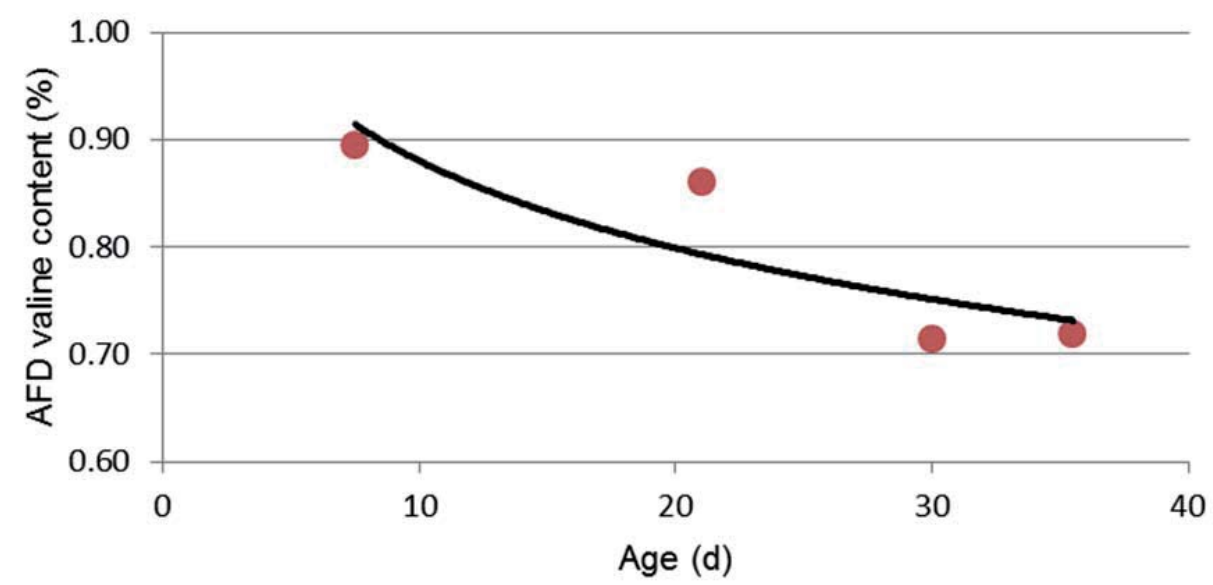

Figure 1 Requirement of AFD valine content (\% in diet) for body weight gain at different ages (based on Exp.no 41, 42, 43, and 71)

The fitted requirement of AFD valine expressed as a percentage of diet for BWG at different ages was based only on four experiments. The relation between the valine requirement and age for BWG on AFD basis was not significant. 
3.2.2 Requirement of AFD valine expressed on dietary content for feed conversion ratio

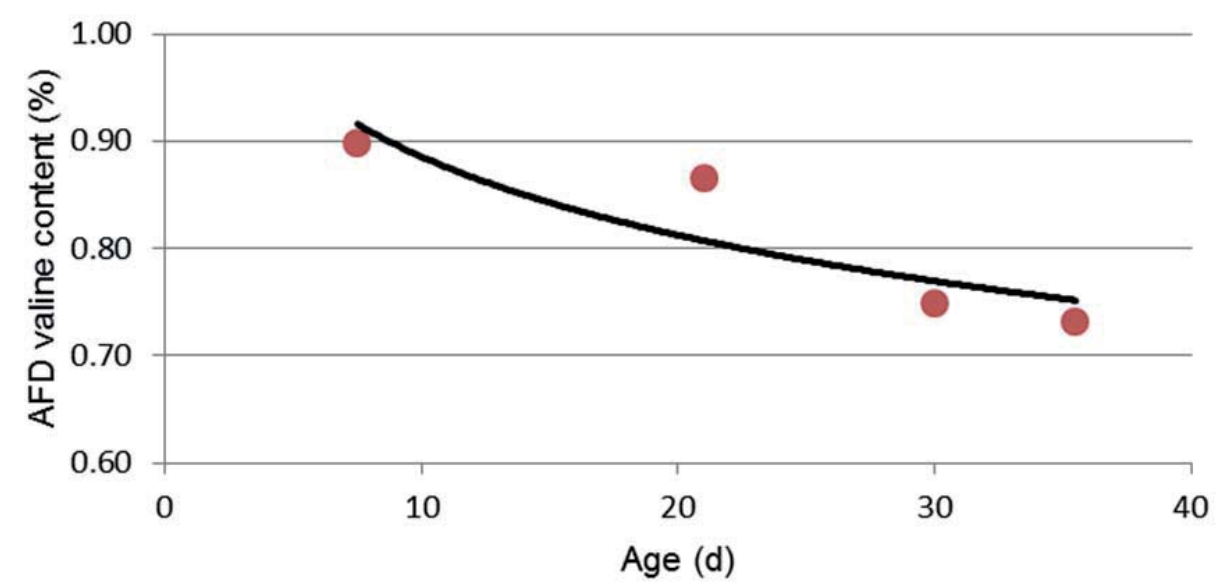

Figure 2 Requirement of AFD valine content (\% in diet) for feed conversion ratio at different ages (based on Exp.no 41, 42, 43 and 71)

The fitted requirement of AFD valine content expressed as a percentage of diet for FCR at different ages was based only on four experiments. The relation between the valine requirement and age for FCR on AFD basis was significant $(P<0.001)$. Although the fit for AFD valine requirement values is nice, it is difficult to derive accurate requirement values for AFD valine for FCR based on these four experiments.

\subsubsection{Requirement of SID valine expressed on dietary content for body weight} gain

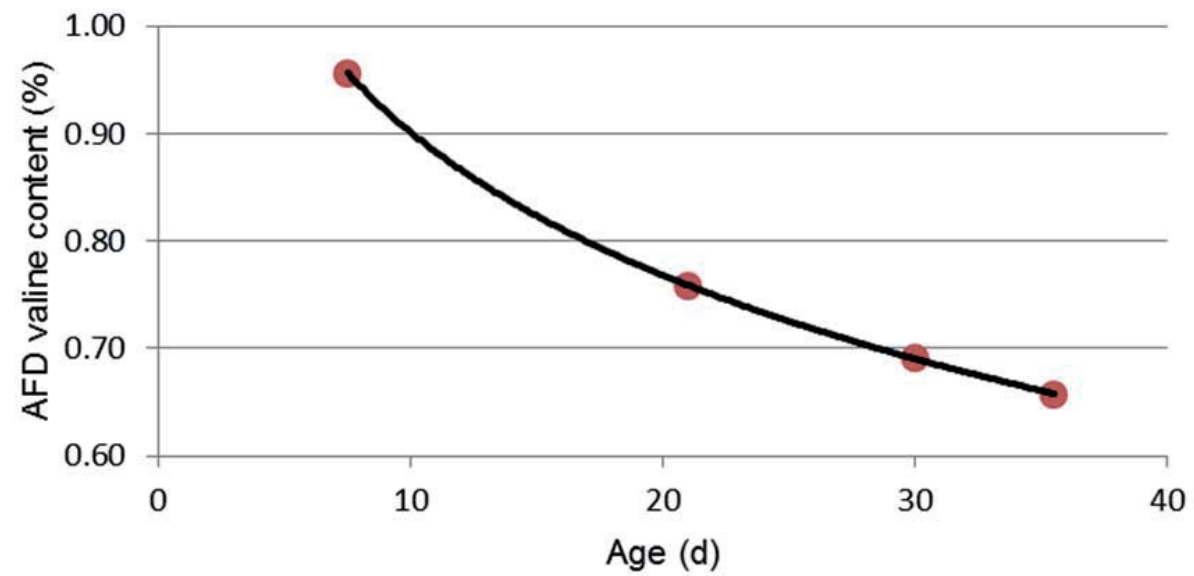

Figure 3 Requirement of SID valine content (\% in diet) for body weight gain at different ages (based on Exp.no 41, 42, 43 and 71)

The fitted requirement of SID valine content expressed as a percentage of diet for BWG at different ages was based only on four experiments. The relation between the valine requirement and age for BWG on SID basis was not significant. 
3.2.4 Requirement of SID valine expressed on dietary content for feed conversion ratio

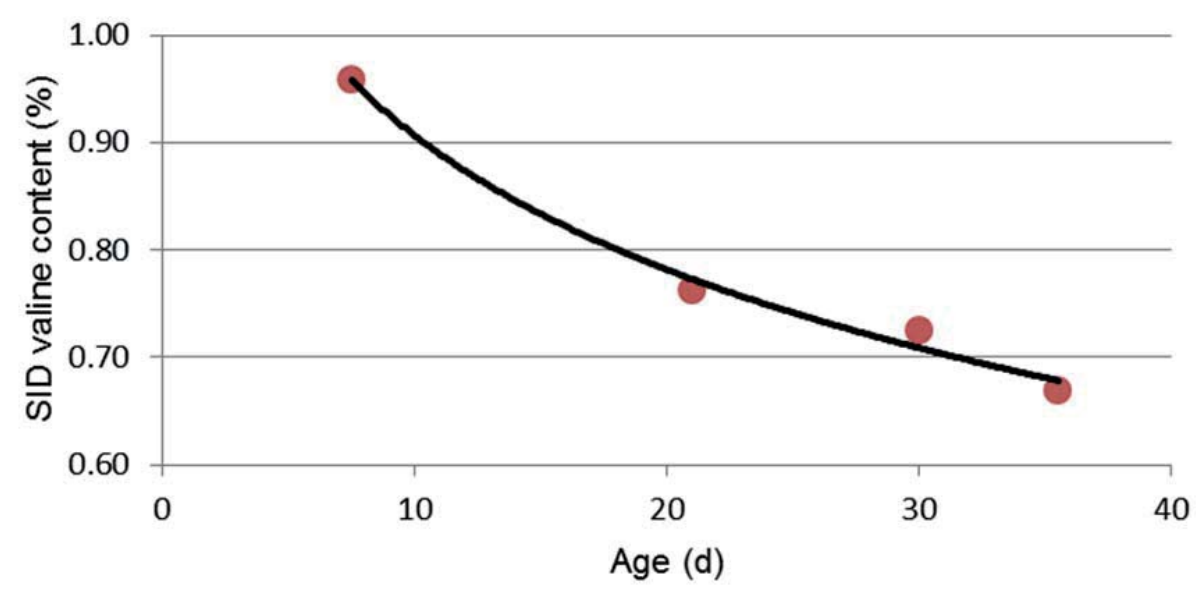

Figure 4 Requirement of SID valine content (\% in diet) for feed conversion ratio at different ages (based on Exp.no 41, 42, 43 and 71)

The fitted requirement of SID valine content expressed as a percentage of diet for FCR at different ages was based only on four experiments. The relation between the valine requirement and age for FCR on SID basis was significant ( $P=0.005)$. Although the fit for SID valine requirement values is nice, it is difficult to derive accurate requirement values for SID valine for FCR based on these four experiments.

\subsection{Requirement values of valine on AFD and SID basis, expressed as content in the diet at different ages for BWG and FCR}

The overall regression analyses for the requirement values of AFD and SID valine content for BWG and FCR as a function of age, resulted in the formulas presented in Table 2. Valine requirement based on AFD as well as SID showed a significant decrease with age for FCR.

Table 2

Mathematical description of the AFD and SID valine requirement, expressed as content in the diet for BWG and FCR as a function of age based on the overall regression analysis (standard errors in brackets)

\begin{tabular}{lll} 
& Overall regression analysis & P-value for age \\
AFD/BWG & $Y=1.151(0.1447)-0.1175(0.04716) * L N($ age $)$ & 0.13 \\
\hline AFD/FCR & $Y=1.343(0.0034)-0.1919(0.00110) * L N($ age $)$ & $<0.001$ \\
\hline SID/BWG & $Y=1.129(0.1224)-0.1057(0.03992) * L N($ age $)$ & 0.12 \\
\hline SID/FCR & $Y=1.321(0.0391)-0.1800(0.01275) * L N($ age $)$ & 0.005 \\
\hline
\end{tabular}

1): $Y=$ valine content in the $\operatorname{diet}(\%)$.

The requirement values of AFD and SID valine content at different ages are presented for FCR in Table 2.

Until 14 days of age the AFD and SID valine requirement values for FCR are slightly higher than the CVB (1996) recommendations for AFD valine requirement. From 17 days of age AFD and SID valine requirement values for FCR were lower than the CVB (1996) recommendations for AFD valine requirement. 
Table 3 Requirement of valine content (\% of diets) according to the regression models for body weight gain and feed conversion ratio

\begin{tabular}{|c|c|c|c|c|c|}
\hline \multirow[t]{2}{*}{ Day } & \multirow{2}{*}{$\begin{array}{c}\text { AFD valine }(\% \text { in } \\
\text { diet }) \\
\text { CVB (2007) }\end{array}$} & \multicolumn{2}{|c|}{ AFD valine ( $\%$ in diet) } & \multicolumn{2}{|c|}{ SI D valine ( $\%$ in diet) } \\
\hline & & $\begin{array}{l}\text { Body } \\
\text { weight } \\
\text { gain }\end{array}$ & $\begin{array}{c}\text { Feed conversion } \\
\text { ratio }\end{array}$ & $\begin{array}{l}\text { Body } \\
\text { weight } \\
\text { gain }\end{array}$ & $\begin{array}{c}\text { Feed conversion } \\
\text { ratio }\end{array}$ \\
\hline 5 & 0.84 & - & 1.03 & - & 1.03 \\
\hline 6 & 0.84 & - & 1.00 & - & 1.00 \\
\hline 7 & 0.84 & - & 0.97 & - & 0.97 \\
\hline 8 & 0.84 & - & 0.94 & - & 0.95 \\
\hline 9 & 0.84 & - & 0.92 & - & 0.93 \\
\hline 10 & 0.84 & - & 0.90 & - & 0.91 \\
\hline 11 & 0.84 & - & 0.88 & - & 0.89 \\
\hline 12 & 0.84 & - & 0.87 & - & 0.87 \\
\hline 13 & 0.84 & - & 0.85 & - & 0.86 \\
\hline 14 & 0.82 & - & 0.84 & - & 0.85 \\
\hline 15 & 0.82 & - & 0.82 & - & 0.83 \\
\hline 16 & 0.82 & - & 0.81 & - & 0.82 \\
\hline 17 & 0.82 & - & 0.80 & - & 0.81 \\
\hline 18 & 0.82 & - & 0.79 & - & 0.80 \\
\hline 19 & 0.82 & - & 0.78 & - & 0.79 \\
\hline 20 & 0.82 & - & 0.77 & - & 0.78 \\
\hline 21 & 0.82 & - & 0.76 & - & 0.77 \\
\hline 22 & 0.82 & - & 0.75 & - & 0.76 \\
\hline 23 & 0.82 & - & 0.74 & - & 0.76 \\
\hline 24 & 0.82 & - & 0.73 & - & 0.75 \\
\hline 25 & 0.82 & - & 0.73 & - & 0.74 \\
\hline 26 & 0.82 & - & 0.72 & - & 0.73 \\
\hline 27 & 0.82 & - & 0.71 & - & 0.73 \\
\hline 28 & 0.79 & - & 0.70 & - & 0.72 \\
\hline 29 & 0.79 & - & 0.70 & - & 0.71 \\
\hline 30 & 0.79 & - & 0.69 & - & 0.71 \\
\hline 31 & 0.79 & - & 0.68 & - & 0.70 \\
\hline 32 & 0.79 & - & 0.68 & - & 0.70 \\
\hline 33 & 0.79 & - & 0.67 & - & 0.69 \\
\hline 34 & 0.79 & - & 0.67 & - & 0.69 \\
\hline 35 & 0.79 & - & 0.66 & - & 0.68 \\
\hline 36 & 0.79 & - & 0.66 & - & 0.68 \\
\hline 37 & 0.79 & - & 0.65 & - & 0.67 \\
\hline 38 & 0.79 & - & 0.64 & - & 0.67 \\
\hline 39 & 0.79 & - & 0.64 & - & 0.66 \\
\hline 40 & 0.79 & - & 0.64 & - & 0.66 \\
\hline 41 & 0.79 & - & 0.63 & - & 0.65 \\
\hline 42 & 0.79 & - & 0.63 & - & 0.65 \\
\hline
\end{tabular}




\title{
Acknowledgement
}

The CVB project group 'Digestible Amino Acids Poultry', consisting of scientists and representatives of the Dutch feed industry, guided this study. The authors would like to acknowledge with much appreciation the members of this project group for their valuable input to all phases of this project. The members of the CVB project group ‘Digestible Amino Acids Poultry' were:

\author{
Alfons Jansman \\ Bart Swart \\ Cees Kwakernaak \\ Carolien Makkink \\ Henk Everts \\ Machiel Blok \\ Marien van den Brink \\ Marinus van Krimpen \\ Mario van Erp \\ Masja Lensing \\ Peter Wijtten \\ Rene Kwakkel \\ Ruud Dekker \\ Teun Veldkamp \\ Walter Gerrits \\ Wouter Spek
}




\section{Literature}

Berres, J., S.L. Vieira, W.A. Dozier III, M.E.M. Cortês, R. de Barros, E.T. Nogueira, M. Kutschenko. 2010a. Broiler responses to reduced-protein diets supplemented with valine, isoleucine, glycine, and glutamic acid. J. Appl. Poult. Res. $19: 68-79$.

Berres, J., S.L. Vieira, M.T. Kidd, D. Taschetto, D.M. Freitas, R. Barros, E.T. Nogueira. 2010b. Supplementing I-valine and I-isoleucine in low-protein corn and soybean meal all-vegetable diets for broilers. J. Appl. Poult. Res. 19 :373-379.

Berres, J., S.L. Vieira, A. Faveroa, D.M. Freitas, J.E.M. Pe na, E.T. Nogueira. 2011. Digestible valine requirements in high protein diets for broilers from twenty-one to forty-two days of age. Animal Feed Science and Technology 165: 120-124.

Corzo, A., E.T. Moran J r., D. Hoehler. 2004. Valine needs of male broilers from 42 to 56 days of age. Poultry Science 83: 946-951.

Corzo, A., W.A. Dozier III, M.T. Kidd. 2008. Valine nutrient recommendations for Ross $\times$ Ross 308 broilers. Poultry Science 87: 335-338.

Corzo, A., R.E. Loar II, M.T. Kidd. 2009. Limitations of dietary isoleucine and valine in broiler chick diets. Poultry Science 88: 1934-1938.

Corzo, A., W.A. Dozier III, R.E. Loar II, M.T. Kidd, P.B. Tillman. 2010. Dietary limitation of isoleucine and valine in diets based on maize, soybean meal, and meat and bone meal for broiler chickens. British Poultry Science 51 (4): 558-563.

Corzo, A., W.A. Dozier III, L. Mejia, C.D. Zumwalt, M.T. Kidd, P.B. Tillman. 2011. Nutritional feasibility of L-valine inclusion in commercial broiler diets. J. Appl. Poult. Res. 20: 284-290.

Dozier III, W.A., P.B. Tillman, J. Usry. 2012. Interactive effects of digestible valine and isoleucine-tolysine ratios provided to male broilers from 4 to 6 weeks of age. J. Appl. Poult. Res. 21: 838848.

CVB. 1996. Amino acid requirement of laying hens and broiler chicks. Schutte, J.B. (ed.). CVB Report No. 18.

CVB. 2007. Veevoedertabel 2007, centraal veevoederbureau. Lelystad, The Netherlands. Uitgave mei 2007.

Dekker, R., and M. C. Blok. 2015 (in press). Gestandaardiseerde ileale aminozuurverteerbaarheid van voedermiddelen voor pluimvee. DVAZP 43.

Mack, S., D. Bercovici, G. De Groote, B. Leclerq, M. Lippens, M. Pack, J.B. Schutte, S. Van Cauwenberghe. 1999. I deal amino acid profile and dietary lysine specification for broiler chickens of 20 to 40 days of age. British Poultry Science. 40 (2): 257 - 265.

Tavernari, F.C., G.R. Lelis, R.A. Vieira, H.S. Rostagno, L.F.T. Albino, A.R. Oliveira Neto. 2013. Valine needs in starting and growing Cobb (500) broilers. Poultry Science 92: 151-157.

Thornton, S.A., A. Corzo, G.T. Pharr, W.A. Dozier III, D.M. Miles, M.T. Kidd. 2006. Valine requirements for immune and growth responses in broilers from 3 to 6 weeks of age. British Poultry Science 47 (2): 190-199. 
Appendices 


\section{Appendix 1 List of references which have not been included in the database with reason}

\begin{tabular}{|c|c|c|}
\hline Reference & Journal & Reason \\
\hline Corzo et al. 2004 & Poultry science & LYS and TRP $<-10 \%$ of limited level \\
\hline Thornton et al. 2006 & British Poultry Science & LYS $<-5 \%$ and TRP $<-10 \%$ of limited level \\
\hline Corzo et al. 2009 & Poultry Science & Supplementation of L-Val and L-Ile both \\
\hline Berres et al. 2010a & J. Appl. Poult. Res. & $\begin{array}{l}\text { Val, Ile, Gly, and Glu supplementation, individually or combined, in broiler diets with gradual } \\
\text { reductions in protein }\end{array}$ \\
\hline Berres et al. $2010 \mathrm{~b}$ & J. Appl. Poult. Res. & Supplementation of L-Val and L-Ile both \\
\hline Corzo et al. 2010 & British Poultry Science & Only two graded levels of supplementation of L-Val or L-Ile \\
\hline Berres et al. 2011 & Anim. Feed Sci. and Techn. & No significant difference in growth between low and high Valine level \\
\hline Corzo et al. 2011 & J. Appl. Poultry Res. & VAL $>-10 \%$ and TRP, ILE and ARG $<10 \%$ of limited level \\
\hline Dozier et al. 2012 & J. Appl. Poult. Res & Supplementation of L-Val and L-Ile both \\
\hline Tavernari et al. 2013 & Poultry science & Calculated CP rel. $6 \%$ lower and AA rel. $10 \%$ higher compared to given data in paper \\
\hline Corzo et al. 2004 & Poultry science & LYS and TRP $<-10 \%$ of limited level \\
\hline Thornton et al. 2006 & British Poultry Science & LYS $<-5 \%$ and TRP $<-10 \%$ of limited level \\
\hline Corzo et al. 2009 & Poultry Science & Supplementation of L-Val and L-Ile both \\
\hline Berres et al. 2010a & J. Appl. Poult. Res. & $\begin{array}{l}\text { Val, Ile, Gly, and Glu supplementation, individually or combined, in } \\
\text { broiler diets with gradual reductions in protein }\end{array}$ \\
\hline Berres et al. 2010b & J. Appl. Poult. Res. & Supplementation of L-Val and L-Ile both \\
\hline Corzo et al. 2010 & British Poultry Science & Only two graded levels of supplementation of L-Val or L-Ile \\
\hline
\end{tabular}




\section{Experimen \\ AFD VAL \\ SI D VAL \\ Exponential Curve for AFD \\ Exponential Curve for SID}

41

$0.90(1.8) \quad 0.90(1.8)$
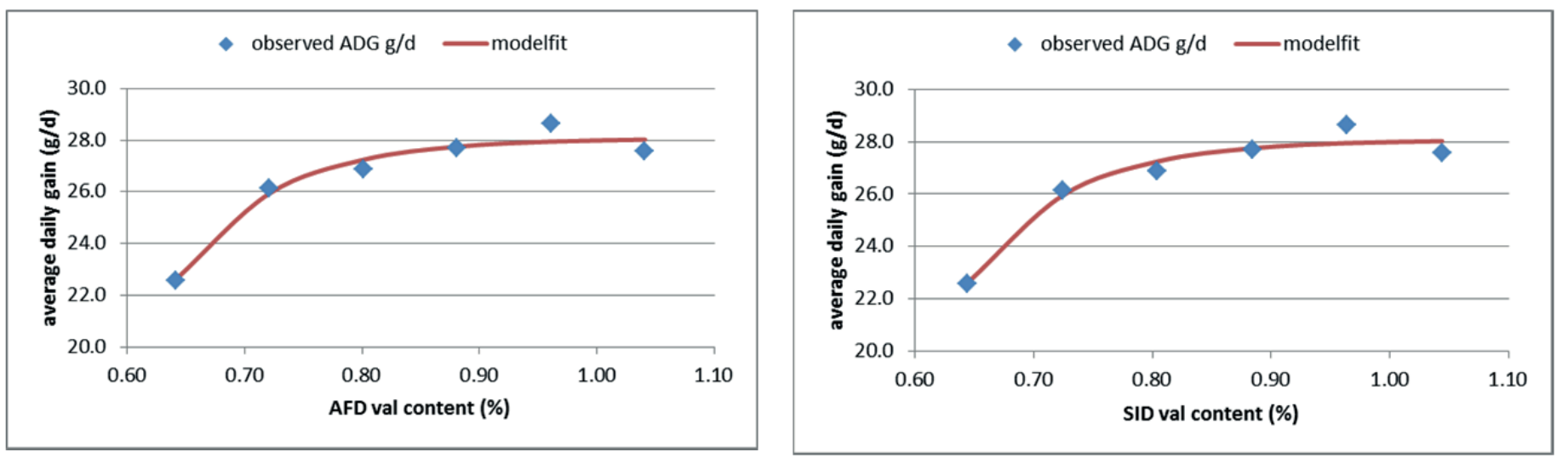

0.86 (1.2) $\quad 0.87(1.2)$
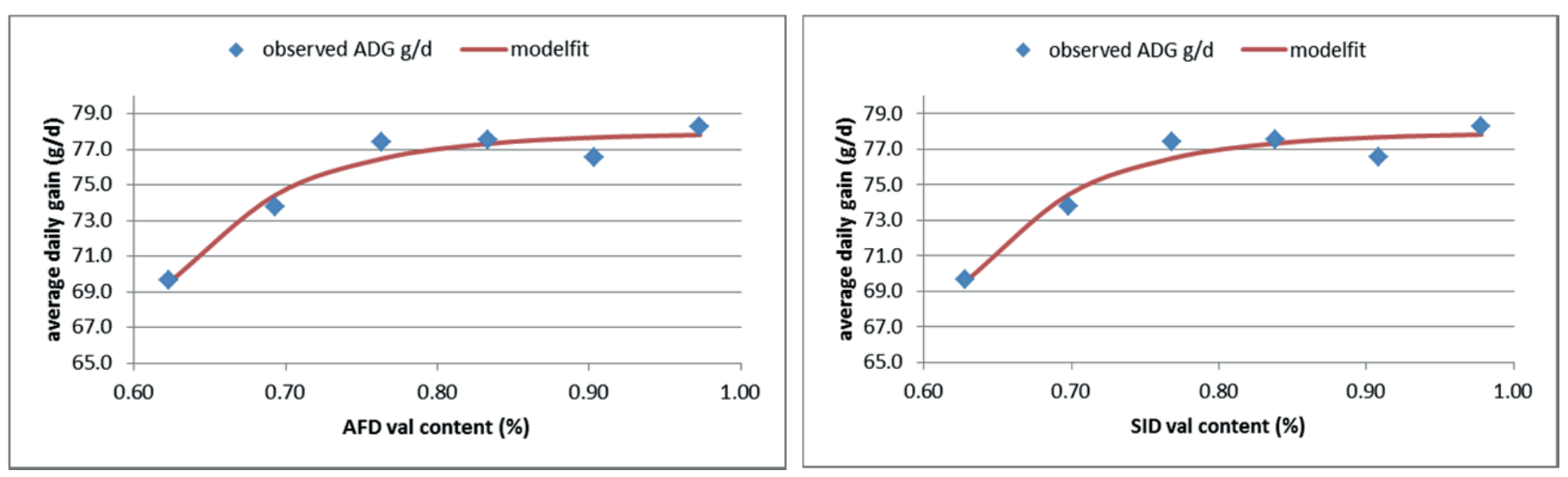
$0.86(1.2) \quad 0.87(1.2)$
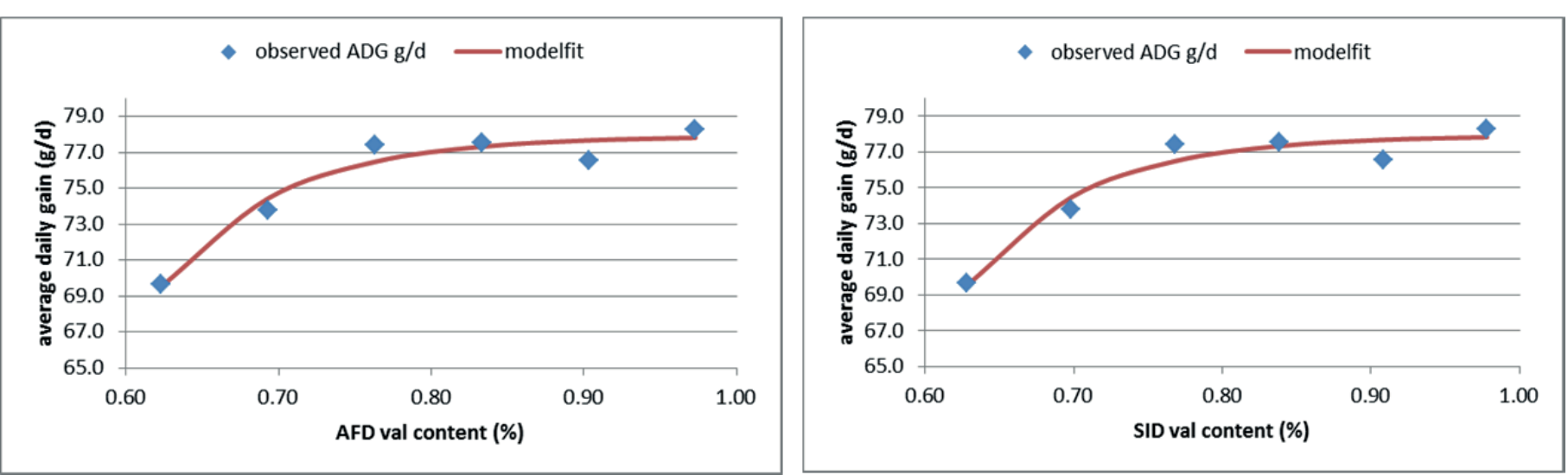

71

$0.73(0.8)$

$0.75(0.8)$

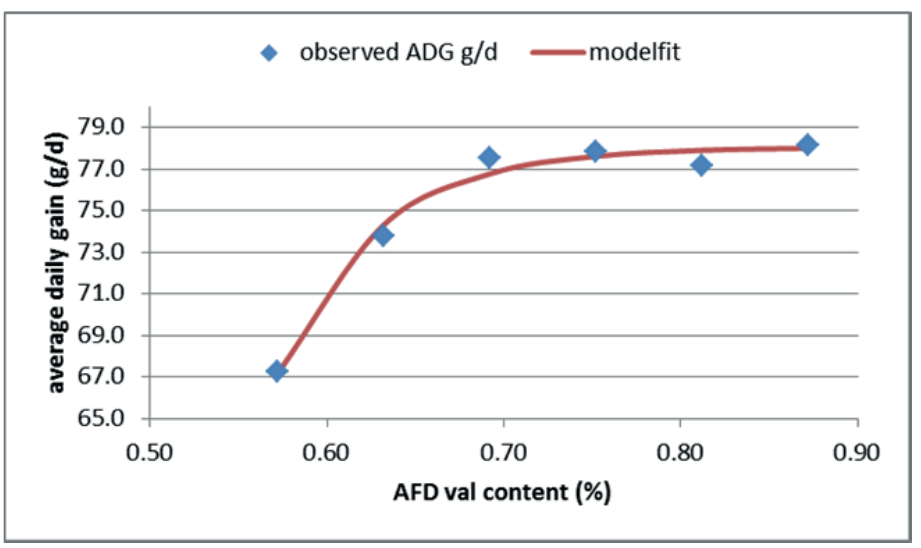


Appendix 3 The determined responses of feed conversion ratio as a function of the AFD and SID valine content for each individual experiment ( $\% \mathrm{CV}=$ coefficient of variation; in brackets)

\section{$\begin{array}{llll}\text { Experiment AFD VAL SI D VAL Exponential Curve for AFD } & \text { Exponential Curve for SI D }\end{array}$}

Number

41

$0.96(1.5) \quad 0.96(1.5)$
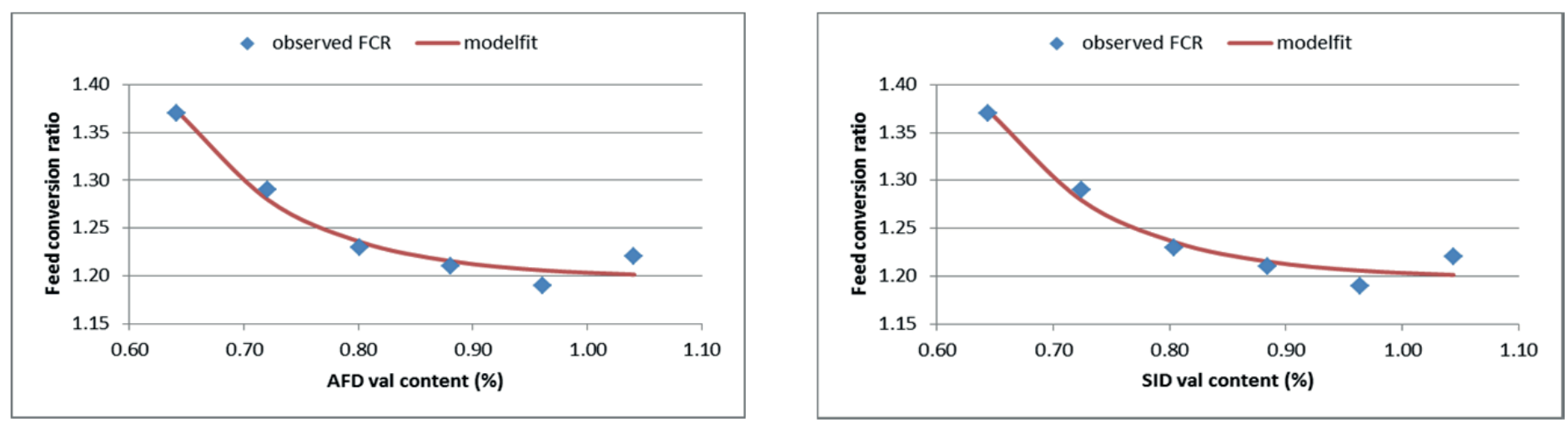

42

$0.76(0.6) \quad 0.76(0.6)$
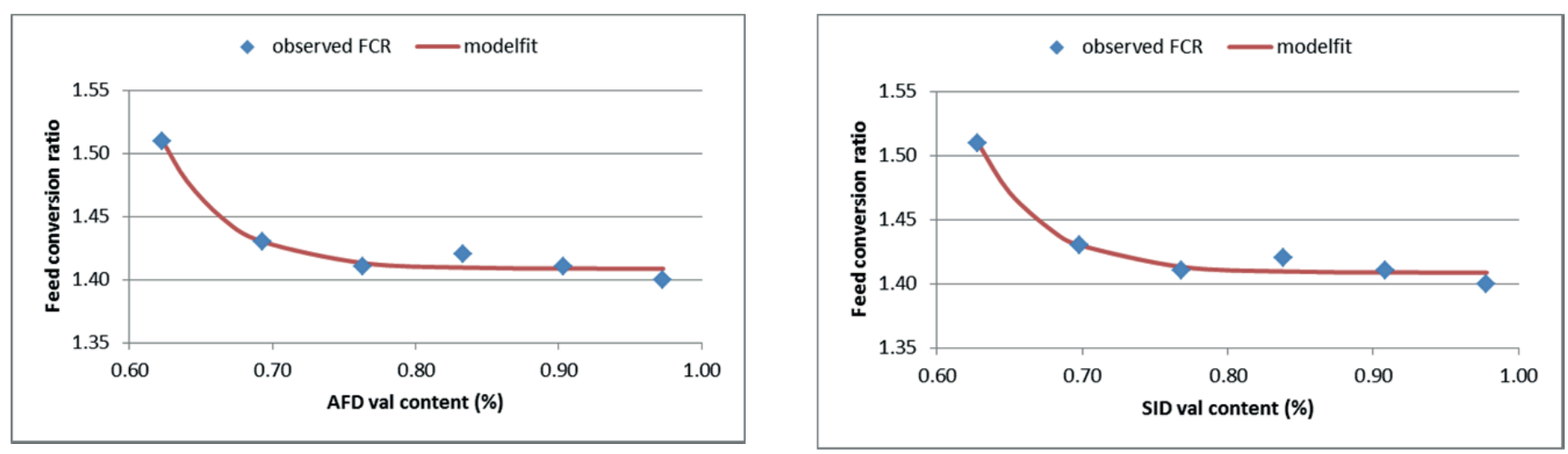
Experiment AFD VAL SID VAL_Exponential Curve for AFD

Number

43

$0.66(1.6) \quad 0.67(1.6)$

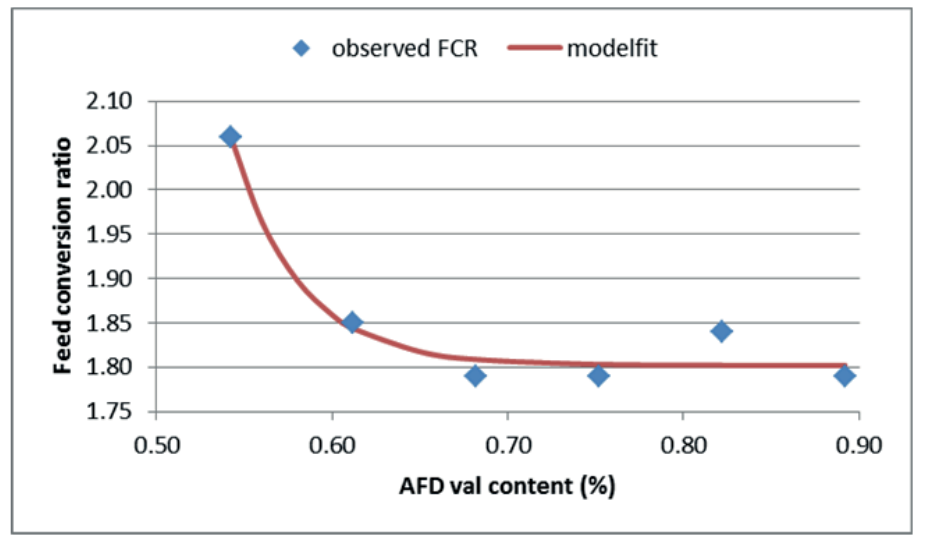

71

$0.69(0.8) \quad 0.73(0.8)$

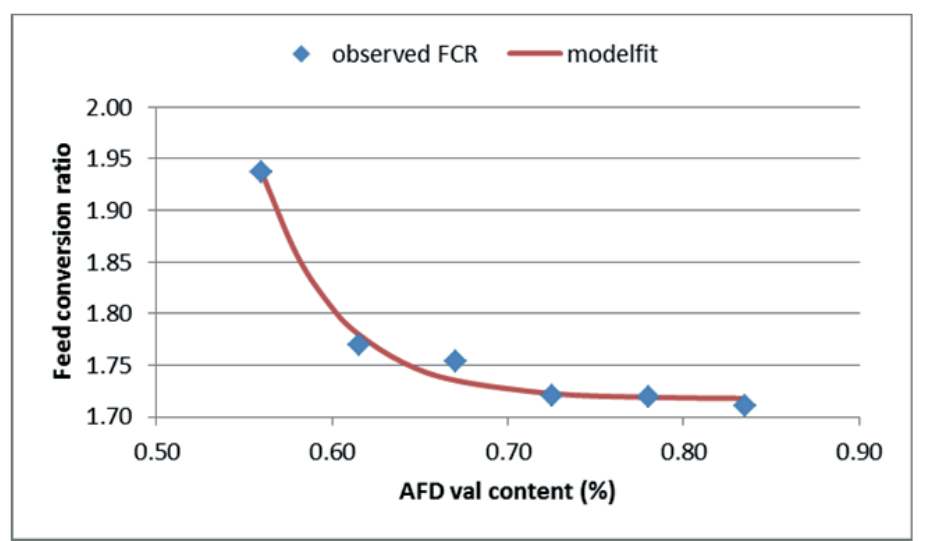

Exponential Curve for SI D
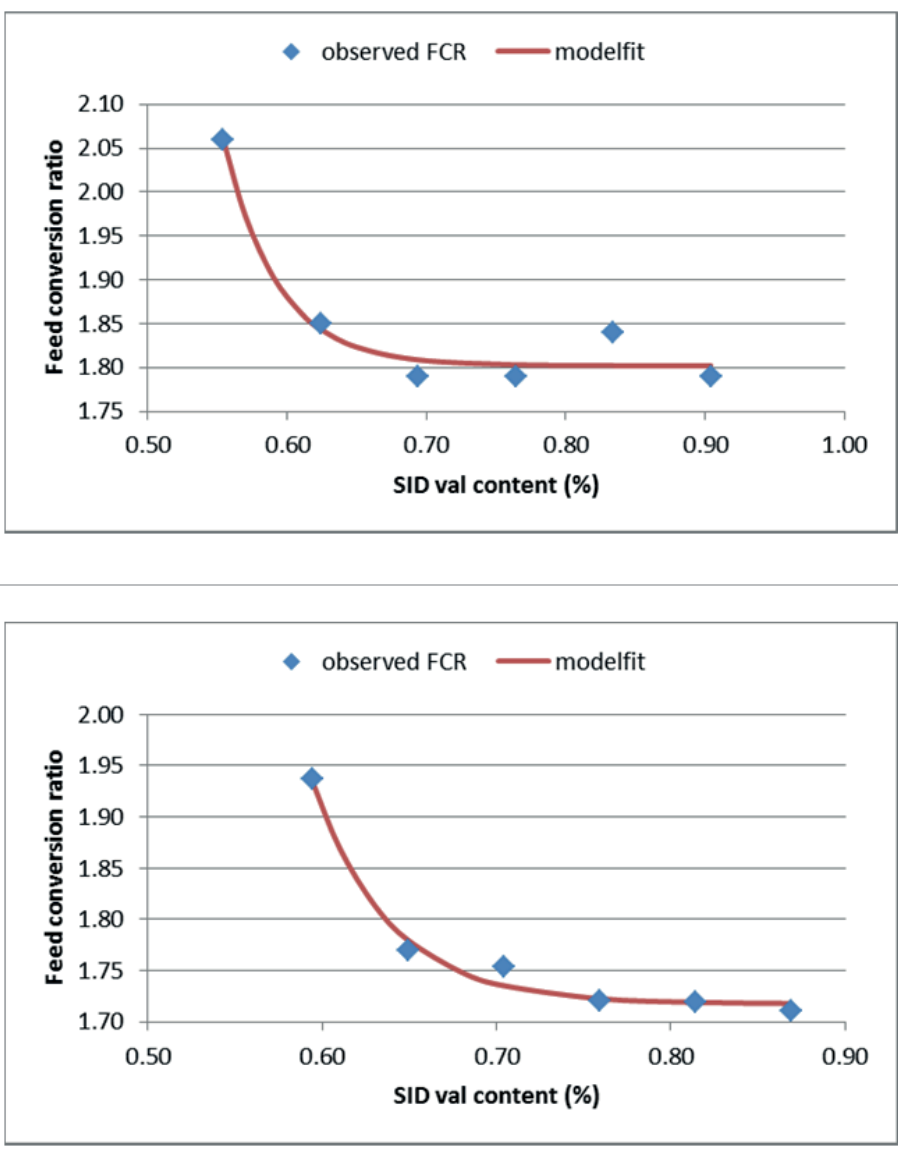
Appendix 4 Experiments for which the requirement on the AFD and SID valine concentration for BWG was estimated according to equation 2 and that also met the criteria for the overall regression to estimate relationship of the AFD and SID

valine requirement for BWG with age

\begin{tabular}{|c|c|c|c|c|c|c|c|c|c|}
\hline \multirow[t]{2}{*}{$\begin{array}{l}\text { Exp } \\
\text { No. }\end{array}$} & \multirow[t]{2}{*}{ Reference } & \multirow[t]{2}{*}{$\begin{array}{l}\text { AFD valine concentration in } \\
\text { the diet }(\%)\end{array}$} & \multirow[t]{2}{*}{ Gender } & \multirow[t]{2}{*}{ Strain } & \multirow[t]{2}{*}{$\begin{array}{l}\text { Age } \\
\text { of } \\
\text { birds }\end{array}$} & \multirow[t]{2}{*}{$\begin{array}{l}\text { Published } \\
\text { Requirement } \\
(\%)\end{array}$} & \multirow[t]{2}{*}{$\begin{array}{l}\text { Models } \\
\text { used by the } \\
\text { reference }\end{array}$} & \multicolumn{2}{|c|}{$\begin{array}{l}\text { Re-calculated } \\
\text { requirement using } \\
\text { exponential models ( } \% \text { ) }\end{array}$} \\
\hline & & & & & & & & $\begin{array}{l}\text { AFD valine } \\
\text { content } \\
\text { for BWG }\end{array}$ & $\begin{array}{l}\text { SID valine } \\
\text { content for } \\
\text { BWG }\end{array}$ \\
\hline 41 & $\begin{array}{l}\text { Corzo et al. } \\
2008\end{array}$ & $0.64,0.72,0.80,0.88,0.96,1.04$ & Male & Ross 308 & $1-14$ & 0.91 & Quadratic & 0.92 & 0.90 \\
\hline 42 & $\begin{array}{l}\text { Corzo et al. } \\
2008\end{array}$ & $0.62,0.69,0.76,0.83,0.90,0.97$ & Male & Ross 308 & $14-28$ & 0.86 & Quadratic & 0.88 & 0.87 \\
\hline 43 & $\begin{array}{l}\text { Corzo et al. } \\
2008\end{array}$ & $0.54,0.61,0.68,0.75,0.82,0.89$ & Male & Ross 308 & $28-42$ & 0.77 & Quadratic & 0.74 & 0.73 \\
\hline 71 & Mack et al. 1999 & $0.56,0.62,0.67,0.73,0.78,0.83$ & Male & ISA 220 & $20-40$ & 0.76 & Quadratic & 0.73 & 0.75 \\
\hline
\end{tabular}


Appendix 5 Experiments for which the requirement on the AFD and SID valine concentration for FCR was estimated according to equation 2 and that also met the criteria for the overall regression to estimate relationship of the AFD and SID valine requirement for FCR with age

\begin{tabular}{|c|c|c|c|c|c|c|c|c|c|}
\hline \multirow[t]{2}{*}{$\begin{array}{l}\text { Exp } \\
\text { No. }\end{array}$} & \multirow[t]{2}{*}{ Reference } & \multirow[t]{2}{*}{$\begin{array}{l}\text { SI D valine } \\
\text { concentration in the } \\
\text { diet }(\%)\end{array}$} & \multirow[t]{2}{*}{ Gender } & \multirow[t]{2}{*}{ Strain } & \multirow[t]{2}{*}{$\begin{array}{l}\text { Age of } \\
\text { birds }\end{array}$} & \multirow[t]{2}{*}{$\begin{array}{l}\text { Published } \\
\text { Requirement } \\
(\%)\end{array}$} & \multirow[t]{2}{*}{$\begin{array}{l}\text { Models used } \\
\text { by the } \\
\text { reference }\end{array}$} & \multicolumn{2}{|c|}{$\begin{array}{l}\text { Re-calculated requirement } \\
\text { using exponential models } \\
(\%)\end{array}$} \\
\hline & & & & & & & & $\begin{array}{l}\text { AFD valine } \\
\text { content } \\
\text { for FCR }\end{array}$ & $\begin{array}{l}\text { SID valine } \\
\text { content for } \\
\text { FCR }\end{array}$ \\
\hline 41 & Corzo et al. 2008 & $\begin{array}{l}0.64,0.72,0.80,0.88 \\
0.96,1.04\end{array}$ & Male & Ross 308 & $1-14$ & 0.91 & Quadratic & 0.96 & 41 \\
\hline 42 & Corzo et al. 2008 & $\begin{array}{l}0.63,0.70,0.77,0.84 \\
0.91,0.98\end{array}$ & Male & Ross 308 & $14-28$ & 0.86 & Quadratic & 0.76 & 42 \\
\hline 43 & Corzo et al. 2008 & $\begin{array}{l}0.55,0.62,0.69,0.76 \\
0.83,0.90\end{array}$ & Male & Ross 308 & $28-42$ & 0.77 & Quadratic & 0.66 & 43 \\
\hline 71 & Mack et al. 1999 & $\begin{array}{l}0.59,0.64,0.70,0.75 \\
0.81,0.86\end{array}$ & Male & ISA 220 & $20-40$ & 0.76 & Quadratic & 0.69 & 0.73 \\
\hline
\end{tabular}



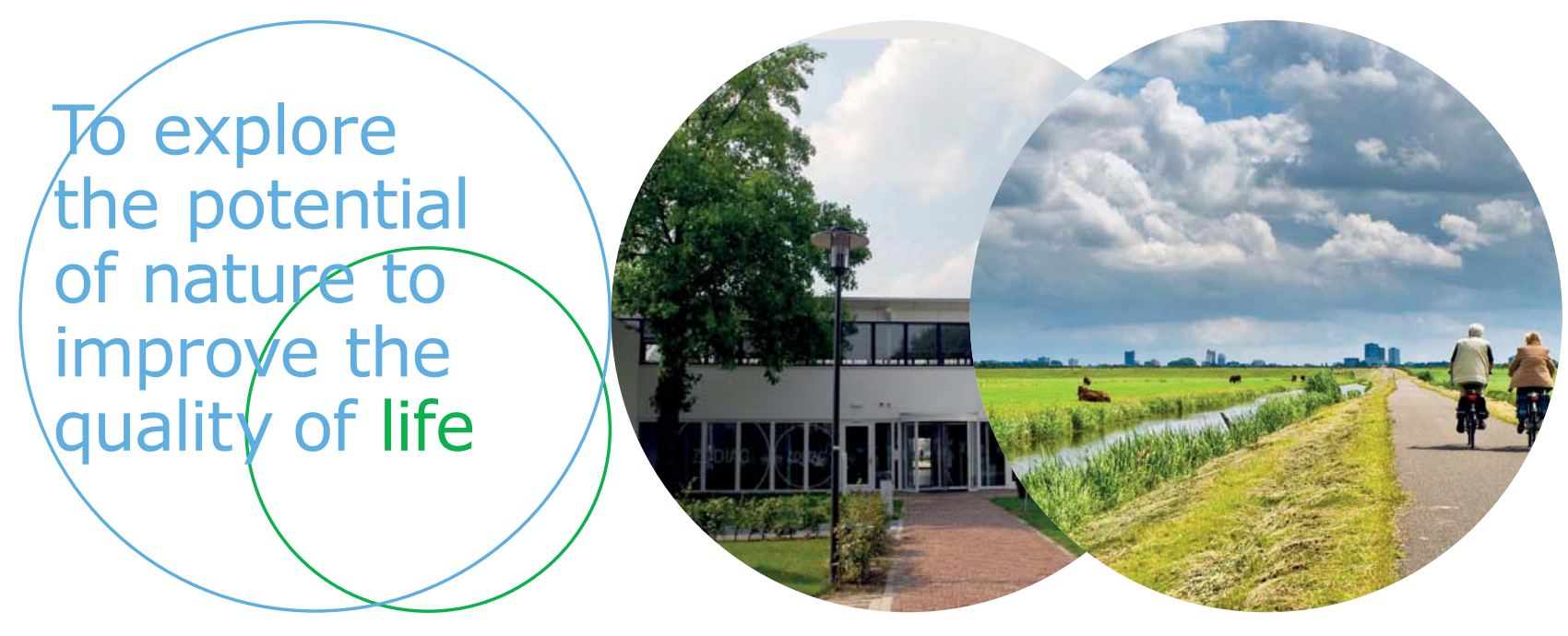

Wageningen UR Livestock Research

P.O. Box 338

$6700 \mathrm{AH}$ Wageningen

The Netherlands

T+31 (0)31748 3953

E info.livestockresearch@wur.nl

www.wageningenUR.nl/livestockresearch
Together with our clients, we integrate scientific know-how and practical experience to develop livestock concepts for the 21st century. With our expertise on innovative livestock systems, nutrition, welfare, genetics and environmental impact of livestock farming and our state-of-the art research facilities, such as Dairy Campus and Swine Innovation Centre Sterksel, we support our customers to find solutions for current and future challenges.

The mission of Wageningen UR (University \& Research centre) is 'To explore the potential of nature to improve the quality of life'. Within Wageningen UR, nine specialised research institutes of the DLO Foundation have joined forces with Wageningen University to help answer the most important questions in the domain of healthy food and living environment. With approximately 30 locations, 6,000 members of staff and 10,000 students, Wageningen UR is one of the leading organisations in its domain worldwide. The integral approach to problems and the cooperation between the various disciplines are at the heart of the unique Wageningen Approach. 